\title{
Changes in soil temperature and moisture due to sugarcane straw removal in central-
}

\section{southern Brazil}

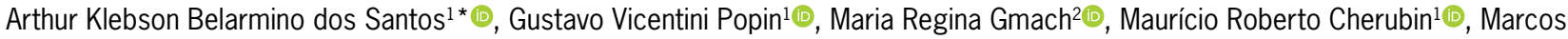 \\ Siqueira Neto ${ }^{3}$, Carlos Eduardo Peregrino Cerri1
}

\author{
Universidade de São Paulo/ESALQ - Depto. de Ciência do \\ Solo, C.P. 09 - 13418-900 - Piracicaba, SP - Brasil. \\ ${ }^{2}$ Swedish University of Agricultural Sciences - Dept. of \\ Ecology, PO Box 7044, SE-75007 - Uppsala - Sweden. \\ 3Universidade de São Paulo/CENA - Lab. de Biogeoquímica \\ Ambiental, C.P. 09 - 13416-900 - Piracicaba, SP - Brasil. \\ *Corresponding author <arthurbelarmino@usp.br>
}

Edited by: Eduardo Alvarez Santos

Received September 26, 2020

Accepted September 03, 2021
ABSTRACT: Crop residues left in the field cover and protect the soil surface, and regulate key processes and functions, such as gas and water exchanges. However, the Brazilian sugarcane (Saccharum officinarum L.) sector has begun to use straw as feedstock to produce bioenergy. We conducted a field study to evaluate the effects of sugarcane straw removal in soil temperature and moisture changes at three sites (with different soil textures: Site 1 - clayey Oxisol, Site 2 - medium texture Oxisol, and Site 3 - sandy Ultisol) in the state of São Paulo, Brazil. The experimental design was randomized blocks with four rates of straw removal: i) no removal (NR); ii) moderate removal (MR); iii) substantial removal (SR), and iv) total removal (TR). Soil temperature was measured by sensors in the 0 - to 5- and 5- to 10-cm soil layers. Undisturbed soil samples were collected from the 0 - to 20 - and 20 - to $40-\mathrm{cm}$ layers to determine soil moisture. Intensive straw removal (HR and TR) increased the soil temperature between 2 and $3{ }^{\circ} \mathrm{C}$ and the thermal amplitude between 5 and $9^{\circ} \mathrm{C}$ in the 0 - to 5-cm layer, compared to MR and NR. Soil moisture decreased between 0.03 and $0.07 \mathrm{~g} \mathrm{~g}^{-1}$ in the 0 - to $20-\mathrm{cm}$ layer with intensive straw removal. The sandy soil was more susceptible to straw removal. Therefore, straw maintenance on the soil surface plays an essential role in temperature regulation and preservation of higher soil moisture, especially in regions with severe water deficits and long periods of water stress.

Keywords: bioenergy, agricultural residues, crop residue management, soil moisture, soil heat

\section{Introduction}

Bioenergy is an important and feasible option for the replacement of fossil fuels, as it reduces greenhouse gas emissions, and, consequently, mitigates global warming and climate change (IPCC, 2019). In spite of this promising alternative, the last decade has seen a rise in the industry's interest in removing the part of straw left in the field to produce bioelectricity or cellulosic ethanol (Carvalho et al., 2019).

The harvesting of green sugarcane (Saccharum officinarum L.) generates between 5 to $20 \mathrm{Mg} \mathrm{ha}^{-1}$ of residues in the field (Leal et al., 2013), forming a 10to $15-\mathrm{cm}$ mulch layer on the soil surface. Maintenance of crop residues on the soil surface confers the following benefits on the soil quality (Cherubin et al., 2021); increased cycling of nutrients (Cherubin et al., 2019), biological activity (Paredes et al., 2015), carbon accumulation (Bordonal et al., 2018), improved structural quality (Castioni et al., 2018), water infiltration (Johnson et al., 2016), and control of erosion (Valim et al., 2016). Furthermore, straw may reduce soil temperatures (Awe et al., 2015) and conserve soil moisture, thereby creating favorable crop growth conditions.

The climate in central-southern Brazil - the largest sugarcane-producing region - is characterized by a six-month dry season. On hot and dry days, high soil temperatures accelerate water loss from the soil surface by evaporation (Corrêa et al., 2019), reducing soil moisture. For this reason, straw plays a fundamental role in regulating soil temperature and preserving soil moisture. However, the influence of straw on soil processes depends on many inherent factors such as soil texture (Bordonal et al., 2018).

Commonly, sandy soils warm up more rapidly than clayey soils due to their lower heat capacity and thermal conductivity (Prevedello, 2010), with the result that these soils lose water by evaporation more easily. Moreover, clayey soils usually have higher organic matter content (Chen et al., 2018), which helps retain more water and act as a sponge, and attenuate the soil temperature.

Therefore, we hypothesized that: i) sugarcane straw acts as a thermal insulator that reduces the soil temperature, and, in turn, the losses of water by evaporation, and preserves the soil moisture; and yet, ii) soil texture affects the dynamics of soil water and temperature. To test these hypotheses, we performed three field experiments to evaluate the impact of sugarcane straw removal rates on soil temperature and moisture in different soil types.

\section{Materials and Methods}

\section{Site description and sampling strategy}

The field experiments were undertaken at three sites located in the state of São Paulo State, southeastern Brazil (Figures 1 and 2) - the country's largest sugarcaneproducing region. The site locations, soil types, climatic conditions, and sugarcane varieties are described in Table 1. Meteorological data (daily mean air temperature 
and precipitation) were obtained from official records of the National Institute of Meteorology (INMET). Rainfall at all sites is concentrated in spring and summer (OctApr), and the dry season is in autumn and winter (MaySept). Due to contrasting soil texture at the study sites, we classified sites 1,2, and 3, as clayey, medium and sandy soil, respectively.

The experimental design was completely randomized blocks, with three repetitions and four rates of straw removal (treatments), including: i) no removal (NR), ii) moderate removal (MR), iii) substantial removal (SR), and iv) total removal (TR, bare soil). The amounts of straw at each site and treatments (Table 2) varied according to the straw yield at each site, which was determined as described by Lisboa et al. (2017). The experiments were installed shortly after the first sugarcane green-harvest and conducted along the first ratoon, starting on 25/10/2015, 15/01/2016 and 20/06/2016 for clayey, medium and sandy, respectively (details in Figure 2).

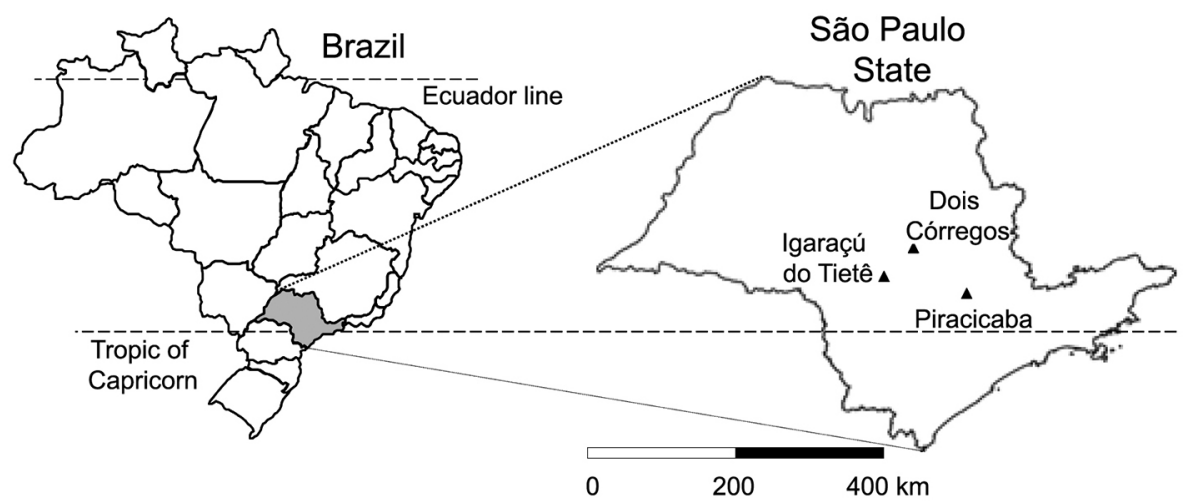

Figure 1 - Geographic location of the study areas in the state of São Paulo, Brazil. i) Igaraçú do Tietê (clayey Oxisol); ii) Piracicaba (medium texture Oxisol) and iii) Dois Córregos (sandy Ultisol).

Table 1 - Location and brief description of soil, climate and sugarcane varieties at each study area.

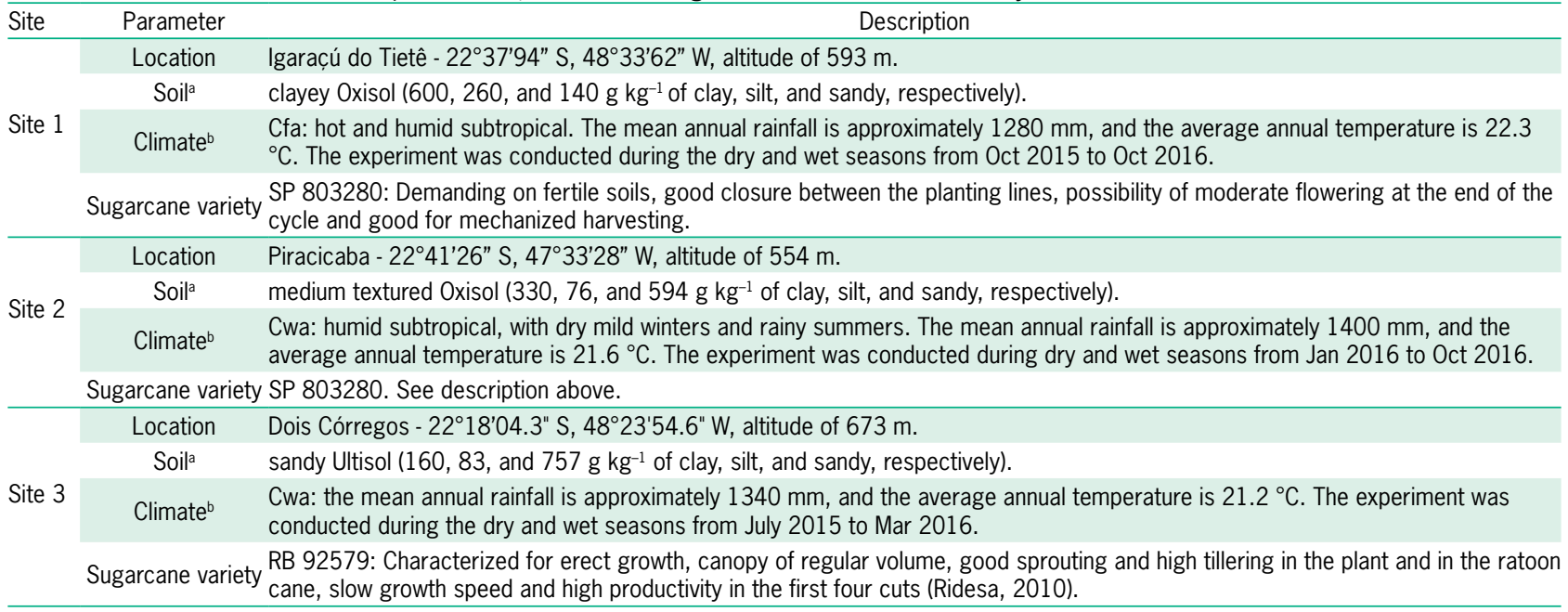

aSoil classification USDA; 呚öppen classification (Alvares et al., 2013).

Table 2 - Treatments, rates of sugarcane straw removal (\%) and amount of the straw remained in the soil surface at the beginning of the experiment.

\begin{tabular}{lcccc}
\hline Straw management & Removal rates & Site 1 - clayey Oxisol & Site 2 - medium texture Oxisol & Site 3-sandy Ultisol \\
\cline { 2 - 5 } Total removal & $\%$ & 0 & Mg ha ${ }^{-1}$ & 0 \\
High removal & 100 & 3.2 & 6 & 6 \\
Moderate removal & 50 & 2 & 3 & 3 \\
No removal & 25 & 7.5 & 12 & 12 \\
\hline
\end{tabular}


Site 1 - Igaraçú do Tietê (clayey Oxisol)

$1^{\text {st }}$ harvest

Experiment instalation (25-10-2015)

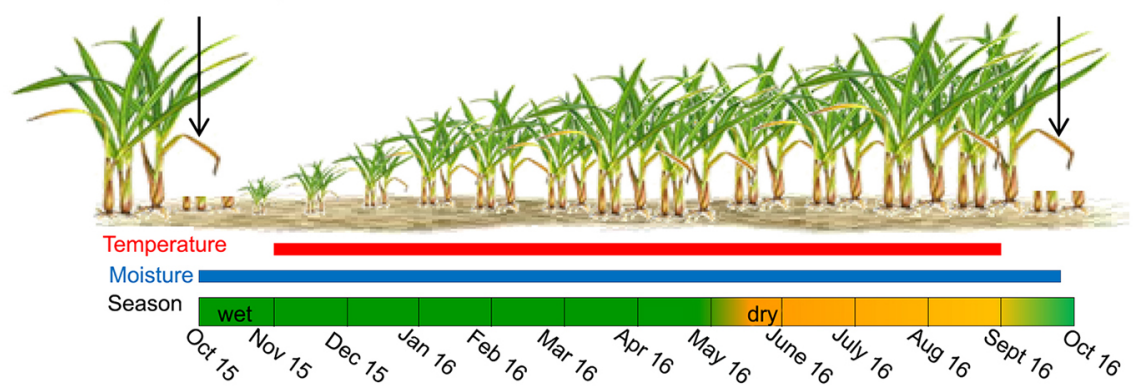

Site 2 - Piracicaba (medium textured Oxisol)

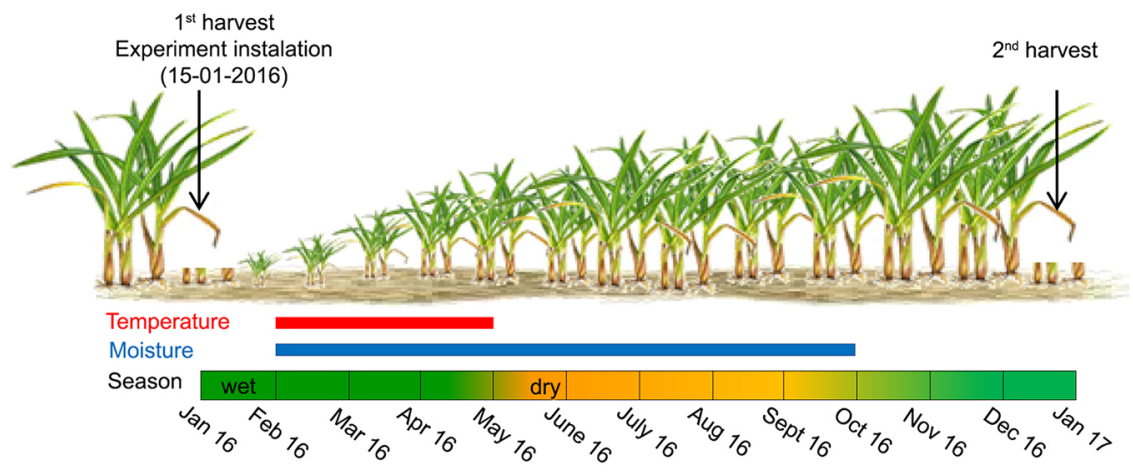

Site 3 - Dois Córregos (sandy Oxisol)

$1^{\text {st }}$ harvest

Experiment instalation

(20-06-2016) $\quad 2^{\text {nd }}$ harvest

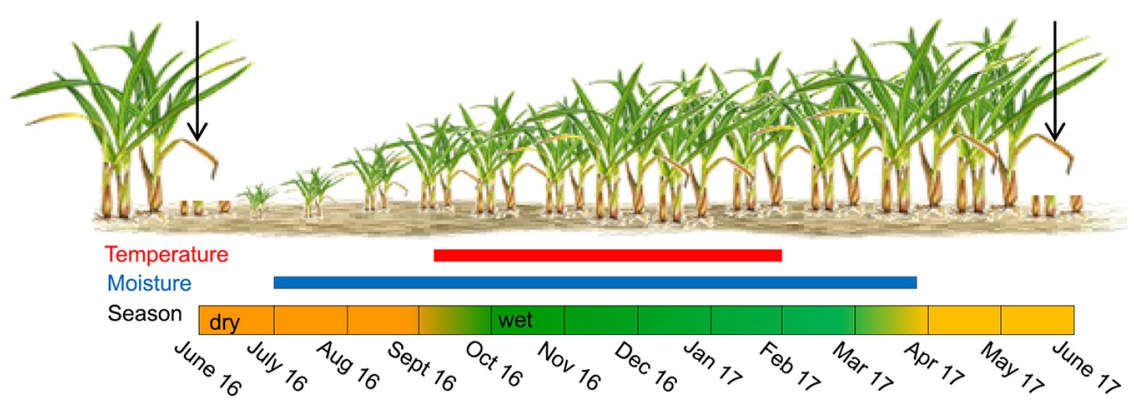

Figure 2 - Experimental activities timeline during the first sugarcane ratoon in the three sites studied.

\section{Soil temperature and moisture measurements}

The soil temperature was recorded in the 0 - to 5- and 5to $10-\mathrm{cm}$ layers, at three points in each plot (totaling nine measures for treatment), located between the sugarcane row and inter-row positions, using an automated system equipped with copper-constantan thermopile sensors. The first thermophile sensor $(0-$ to $5-\mathrm{cm})$ was located in the 2.5- and 3-cm layer, while the second one (5- to 10$\mathrm{cm})$ was in the 7.5- and 8-cm layer. This information was added to the text. Dataloggers were installed to record and store data automatically at each 60-min interval. Certain technical problems (e.g., battery discharge, electric short-circuit) during the experiments resulted in periods with lack of data. In addition, we depended on the sugarcane harvest for the experiment's installation. Thus, we were unable to avoid differences in seasonality.

The soil temperature measurements were taken for ten months (clayey) in wet/dry seasons, three months (medium) in the wet season and seven months (sandy) 
wet/dry seasons. At each site, one day was selected in the dataset to elucidate the effects of straw removal on hourly soil temperatures. The day chosen was a typical sunny day, with high mean air temperature and no rainfall. The effect of amounts of sugarcane straw on the soil thermal amplitude (the difference between daily maximum and daily minimum soil temperature) was also evaluated.

Soil moisture on undisturbed samples collected from the same plots also at three points was determined (totaling nine samples for treatment), located between the sugarcane row and inter-row positions, using a mechanical drill to dig down to the 0- to 20- and 20- to 40-cm layers. Soil samples were taken every 15 days in the initial phase of crop growth and at more extended periods ( 30 days) after the cane field closure. High rainfall delayed, soil samplings as the soil became homogeneous, making it impossible to observe the effect of the treatments. The soil moisture measurements were taken during the wet/dry seasons for 12 months (clayey), seven months (medium) and eight months (sandy). Soil water content was determined by oven-drying $\left(105^{\circ} \mathrm{C}\right)$ the samples to constant mass (Teixeira et al., 2017).

\section{Statistical analysis}

Soil temperature and moisture data were analyzed by analysis of variance (ANOVA) and, where significant ( $\mathrm{F}$ test $<0.05)$, the means were compared by Tukey's test $(p<0.05)$. All statistical analyses were carried out using the SAS v. 9.3 software program (SAS Institute Inc., Cary, NC, USA).

\section{Results}

\section{Effect of straw removal on soil temperature and moisture}

Air temperature ranged from 17.3 to $26.4{ }^{\circ} \mathrm{C}$ (clayey), 15.5 to $29.7{ }^{\circ} \mathrm{C}$ (medium), and 18.2 to $24.6^{\circ} \mathrm{C}$ (sandy), while the soil temperature ranged from 15.7 to $28.5^{\circ} \mathrm{C}$ (clayey), 15.5 to $26.9^{\circ} \mathrm{C}$ (medium), and 18.2 to $26.1{ }^{\circ} \mathrm{C}$ (sandy) (Figure 3).

The sugarcane straw management affected soil temperature, but the impacts were significant mainly in the initial growth phase (first four months of development). Intensive straw removal (SR and TR) increased the soil temperature between 2 and $3{ }^{\circ} \mathrm{C}$ in the 0 - to 5-cm layer, on average, compared to MR and NR ( $p$ $<0.05$; Figures 3 and 4; Table 3). However, the highest reduction was $3{ }^{\circ} \mathrm{C}$ in sandy soil in the dry season, followed by clayey and medium soils, with $2.4^{\circ} \mathrm{C}$ and $2{ }^{\circ} \mathrm{C}$ (wet season), respectively. As expected, there was an ever-greater reduction in the soil temperature as the straw amount increased.

Comparing intensive straw removal and MR and NR, the increase in the straw removal resulted in a higher thermal amplitude variation, reaching values up to $9{ }^{\circ} \mathrm{C}, 5.5^{\circ} \mathrm{C}$, and $5^{\circ} \mathrm{C}$ for clayey, medium, and sandy soils, respectively (Figure 3) in the 0 - to $5-\mathrm{cm}$ layer. Although the measurement periods are different, the highest temperatures were recorded between Dec and Feb in the sandy soil, with the sugarcane at an advanced development stage. During the winter, the soil temperature ranged from 16 to $22^{\circ} \mathrm{C}$ at the three sites.

The hourly soil temperature (between $10 \mathrm{~h} 00$ to $18 \mathrm{~h} 00$ ) varied across treatments, with the maximum value observed around $15 \mathrm{~h} 00$ in the 0 - to 5 -cm layer in $\mathrm{SR}$ and TR, (Figure 5). Maximum values were between 33 and $36^{\circ} \mathrm{C}$ for (SR and TR), and 22 and $30{ }^{\circ} \mathrm{C}$ for (MR and NR), with differences up to $7.3^{\circ} \mathrm{C}, 5.7^{\circ} \mathrm{C}$, and $12.6{ }^{\circ} \mathrm{C}$ for clayey, medium and sandy soil, respectively. Soil temperature decreased with depth, regardless of straw management. In the 0 - to $5-\mathrm{cm}$ layer, soil temperatures were higher than the air temperature.

The soil moisture content under sugarcane straw management was driven by rainfall (Figure 6) and air temperature (Figure 3). With the exception of sandy soil - which presented an increase in soil moisture as the straw amount increased - the medium and clayey soils had very similar results across the various applications of management. During the initial growth phase, comparing intensive straw removal with $\mathrm{MR}$ and NR, soil moisture decreased up to $0.07,0.03$ in the wet season, and $0.07 \mathrm{~g} \mathrm{~g}^{-1}$ in the dry season in the 0 - to $20-\mathrm{cm}$ layer, for clayey, medium, and sandy soils, respectively $(p<0.05$; Figure 5; Table 3). Overall, soil moisture in the sandy soil decreased $0.07 \mathrm{~g} \mathrm{~g}^{-1}$ during the dry season with both substantial and total straw removal (SR and TR). In the 20- to 40-cm layer, except for clayey soil, the results were very similar to those for the $0-$ to $20-\mathrm{cm}$ layer, with reductions of up to $0.02,0.03$, and $0.06 \mathrm{~g} \mathrm{~g}^{-1}$ for clayey, medium, and sandy soils, respectively $(p<$ 0.05; Figure 6; Table 3).

\section{Discussion}

\section{Effects of sugarcane straw removal on soil temperature}

Maintenance of crop residues on the soil surface has been reported as an important management practice that reduces the soil temperature (Zwirtes et al., 2017) and thermal amplitude (Coelho et al., 2013), which in turn, contribute to reducing water losses by evaporation. In this study, significant effects of the straw managements on the soil temperature were observed, mainly in the near-surface soil layer. Our results indicated an increase between 2 and $3{ }^{\circ} \mathrm{C}$ in the soil temperature in the 0 - to 5 -cm layer when compared with intensive straw removal with MR and NR (Figure 3; Table 3).

The main impact of straw management on the soil temperature was observed during the initial growth phase (Figure 4), since the bare soil absorbs a greater amount of solar radiation, warming up more than soils covered with straw. According to our results, sandy soil presented the greatest reduction in the soil temperature 
during the dry season $\left(3{ }^{\circ} \mathrm{C}\right.$ in the 0 - to 5 -cm layer $)$ with intensive straw removal (Figure 3; Table 3). Despite having less heat conductivity and less heat stored for less time, sandy soils heat up more than clayey soils (Townsend, 1977).

The most significant soil thermal amplitude was recorded in the 0 - to 5 - $\mathrm{cm}$ layer in $\mathrm{TR}$, reaching up to 9
${ }^{\circ} \mathrm{C}$ (Figure 3) in the clayey soil in Feb (during the initial growth phase). It coincided with the period when the highest air temperatures were recorded. The reduction observed in the soil temperature and thermal amplitude varying according to the depth may be the result of the relatively higher heat capacity induced by higher soil moisture. Similar results were found in sugarcane fields

\section{Site 1 - clayey Oxisol Site 2 - medium texture Oxisol Site 3 - sandy Ultisol}



Figure 3 - Air temperature and rainfall, and measured average soil temperature and thermal amplitude at the 0- to 5- and 5- to 10- cm depths under sugarcane straw removal rates (TR = total removal; $M R=$ medium removal; $H R=$ high removal and $\mathrm{NR}=$ no removal). i) clayey $0 x i s o l ;$ ii) medium texture Oxisol and iii) sandy Ultisol. 
Table 3 - Effect of different crop residues on soil temperature and moisture.

\begin{tabular}{|c|c|c|c|c|c|c|c|c|}
\hline \multirow{2}{*}{ Location } & \multirow{2}{*}{$\begin{array}{l}\text { Soil and climate } \\
\text { classification }^{\dagger}\end{array}$} & \multicolumn{3}{|c|}{ Soil temperature $\left({ }^{\circ} \mathrm{C}\right)$} & \multicolumn{3}{|c|}{ Soil moisture ( $\mathrm{g} \mathrm{g}^{-1}$ ) } & \multirow{2}{*}{ Reference } \\
\hline & & Soil depth & With straw & Without straw & Soil depth & With straw & Without straw & \\
\hline & & $\mathrm{cm}$ & & & $\mathrm{cm}$ & & & \\
\hline \multicolumn{9}{|c|}{ Sugarcane (Saccharum officinarum) } \\
\hline \multirow{2}{*}{ Igaraçu do Tietê, Brazil } & \multirow{2}{*}{$\begin{array}{l}\text { Oxisol } \\
\text { (Cfa) }\end{array}$} & $0-5$ & 25.6 & 28.1 & $0-20$ & 0.28 & 0.21 & \multirow{6}{*}{ This study } \\
\hline & & $5-10$ & 25.2 & 26.6 & $20-40$ & 0.27 & 0.25 & \\
\hline \multirow{2}{*}{ Piracicaba, Brazil } & \multirow{2}{*}{$\begin{array}{l}\text { Oxisol } \\
\text { (Cwa) }\end{array}$} & $0-5$ & 22.4 & 24.6 & $0-20$ & 0.13 & 0.10 & \\
\hline & & $5-10$ & 22.0 & 24.1 & $20-40$ & 0.12 & 0.09 & \\
\hline \multirow{2}{*}{ Dois Córregos, Brazil } & \multirow{2}{*}{$\begin{array}{l}\text { Ultisol } \\
\text { (Cwa) }\end{array}$} & $0-5$ & 20.0 & 22.9 & $0-20$ & 0.15 & 0.08 & \\
\hline & & $5-10$ & 19.4 & 20.0 & $20-40$ & 0.16 & 0.10 & \\
\hline Piracicaba, Brazil & Rhodic Kandiudox (Cfa) & $3-9$ & 23.2 & 30.1 & - & - & - & Dourado-Neto et al. (1999) \\
\hline Piracicaba, Brazil & Rhodic Kandindox (Cfa) & $3-9$ & 23.1 & 30.1 & - & - & - & Oliveira et al. (2001) \\
\hline \multirow{2}{*}{ Araras, Brazil } & \multirow{2}{*}{$\begin{array}{l}\text { Oxisol } \\
\text { (Cwa) }\end{array}$} & - & - & - & $0-20$ & 0.32 & 0.31 & \multirow{2}{*}{ Peres et al. (2010) } \\
\hline & & - & - & - & $20-40$ & 0.35 & 0.36 & \\
\hline \multirow[b]{2}{*}{ Tucamán, Argentina } & \multirow{2}{*}{ Argiustoll (Cfa) } & \multirow{2}{*}{$0-15$} & \multirow{2}{*}{21.0} & 27.0 & $0-20$ & 0.28 & 0.24 & \\
\hline & & & & & $20-40$ & 0.26 & 0.24 & Digonzelli et al. (2011) \\
\hline Quatá, Brazil & Arenic Kandidult $\left(\mathrm{Aw}^{2}\right)$ & $0-15$ & 18.0 & 24.0 & $0-15$ & 0.11 & 0.09 & \\
\hline Chapadão do Céu, Brazil & Rhodic Hapludox $\left(\mathrm{Aw}^{2}\right)$ & $0-15$ & 20.0 & 25.0 & $0-15$ & 0.34 & 0.45 & Corrêa et al. (2019) \\
\hline Quirinópolis, Brazil & Rhodic Eutrudox $\left(\mathrm{Aw}^{2}\right)$ & $0-15$ & 21.5 & 28.0 & $0-15$ & 0.32 & 0.34 & \\
\hline & Dystrophic Paleudalf & $0-5$ & 28.1 & 32.2 & $0-5$ & 0.24 & 0.22 & \\
\hline Santa Ilarıa, Brazil & (Cfa) & $5-10$ & 27.1 & 30.9 & $5-10$ & 0.25 & 0.23 & Awe et al. (2015) \\
\hline Sugarcane mean \pm S.E. & & & $22.7 \pm 3.0$ & $26.7 \pm 3.5$ & & $0.24 \pm 0.1$ & $0.22 \pm 0.1$ & \\
\hline Others crops & & & & & & & & \\
\hline $\begin{array}{l}\text { Potato (Solanum } \\
\text { tuberosum) } \\
\text { El Zamorano, Honduras }\end{array}$ & $\begin{array}{l}\text { Sandy loam soil } \\
\text { (BSk) }\end{array}$ & $0-2$ & 18.2 & 27.2 & $0-6$ & 0.65 & 0.60 & Awan (1964) \\
\hline & & $0-5$ & 34.0 & 42.0 & ח-10 & 12 & 0 & \\
\hline $\begin{array}{l}\text { Rice (Uryza satıva) } \\
\text { lbadan, Nigeria }\end{array}$ & $\begin{array}{l}\text { Clayey soll } \\
\text { (Aw) }\end{array}$ & $5-10$ & 33.0 & 37.0 & $0-10$ & 0.12 & 0.09 & Lal (1974) \\
\hline & & $10-20$ & 32.0 & 34.0 & $10-20$ & 0.10 & 0.08 & \\
\hline $\begin{array}{l}\text { Rye (Secale cereal) } \\
\text { Siedlce, Poland }\end{array}$ & $\begin{array}{l}\text { Luvisol } \\
\text { (Dfb) }\end{array}$ & $0-10$ & 16.0 & 23.0 & - & - & - & Kosterna (1989) \\
\hline Barley (Hordeum vulgare) & Udic Boroll & $0-5$ & 18.2 & 19.1 & $0-15$ & 0.38 & 0.36 & \\
\hline Ellerslie, Canada & (Dfb) & $5-10$ & 13.8 & 14.9 & $15-30$ & 0.36 & 0.36 & \\
\hline Barley (Hordeum vulgare) & Boralfic Boroll & $0-5$ & 21.4 & 21.4 & $0-15$ & 0.20 & 0.19 & Nyborg and Malhi (1989) \\
\hline Cooking Late, Canada & (Dfb) & $5-10$ & 17.2 & 17.3 & $15-30$ & 0.19 & 0.18 & \\
\hline & & $0-2$ & 25.9 & 28.9 & & & & \\
\hline Black oat (Avena strigosa) & $\begin{array}{c}\text { Oxisol } \\
\text { (Cfa) }\end{array}$ & $0-5$ & 26.1 & 28.1 & - & - & - & Gasparim et al. (2005) \\
\hline & & $0-10$ & 25.8 & 27.9 & & & & \\
\hline & & $0-2.5$ & 22.1 & 25.5 & $0-2.5$ & 0.34 & 0.30 & \\
\hline $\begin{array}{l}\text { Mucuna (Mucuna pruriens) } \\
\text { Vicosa Brazil }\end{array}$ & $\begin{array}{l}\text { Oxisol } \\
\text { (Cfa) }\end{array}$ & $0-5$ & 21.9 & 24.6 & $0-5$ & 0.36 & 0.33 & Oliveira et al. (2005) \\
\hline & & $0-7.5$ & 22.0 & 24.1 & $0-7.5$ & 0.35 & 0.33 & \\
\hline $\begin{array}{l}\text { Wheat (Avena sativa) } \\
\text { Shijiazhuang, China }\end{array}$ & $\begin{array}{l}\text { Gleysoil } \\
\text { (BSk) }\end{array}$ & $0-10$ & 8.0 & 14.0 & - & - & - & Chen et al. (2007) \\
\hline $\begin{array}{l}\text { Black oat }+ \text { fodder turnip } \\
\text { (Avena strigosa }+ \\
\text { Raphanus sativus) } \\
\text { Botucatu, Brazil }\end{array}$ & $\begin{array}{l}\text { Nitossol } \\
\text { (Cfa) }\end{array}$ & $0-5$ & 29.1 & 31.8 & $0-10$ & 0.26 & 0.24 & Furlani et al. (2008) \\
\hline $\begin{array}{l}\text { Citrus (Citrus sinensis L. } \\
\text { Osbeck) } \\
\text { Danjiangkou, China }\end{array}$ & $\begin{array}{l}\text { Cinnamon yellow } \\
\text { (Cfa) }\end{array}$ & $0-5$ & 18.6 & 20.3 & $0-20$ & 0.23 & 0.19 & Liu et al. (2014) \\
\hline Maize (Zea mays) & Silt loam soil & & & - & $0-20$ & 0.24 & 0.21 & 7 han et al (2014) \\
\hline Inner Mongolia, China & (BSk) & - & - & & $20-40$ & 0.27 & 0.25 & \\
\hline $\begin{array}{l}\text { White oat (Avena sativa) } \\
\text { Santa Maria, Brazil }\end{array}$ & $\begin{array}{l}\text { Dystrophic Paleudalf } \\
\text { (Cfa) }\end{array}$ & $0-5$ & 23.0 & 31.5 & - & - & - & Ribas et al. (2015) \\
\hline Sorghum (Sorghum & & & & & $0-2$ & 0.29 & 0.18 & \\
\hline bicolor) & $\begin{array}{l}\text { Chromic vertisol } \\
\text { (BSh) }\end{array}$ & - & - & - & $2-4$ & 0.14 & 0.13 & Teame et al. (2017) \\
\hline Tigray, Ethiopia & & & & & $4-6$ & 0.15 & 0.12 & \\
\hline Others crops mean \pm S.E. & & & $22.0 \pm 6.8$ & $26.0 \pm 7.4$ & & $0.27 \pm 0.13$ & $0.24 \pm 0.13$ & \\
\hline
\end{tabular}

†Soil and climate classification were reported as described in the original paper. 
(30 DAH)
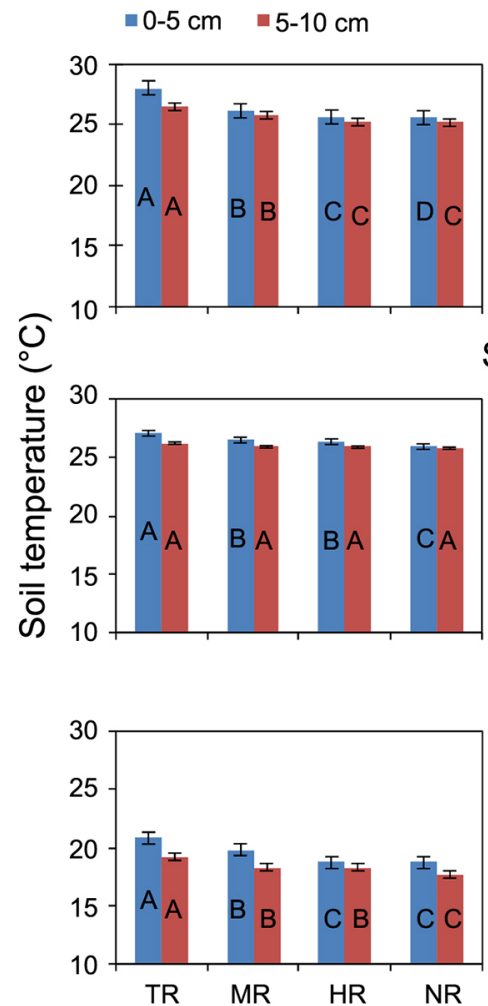

(120 DAH)

Site 1 - clayey Oxisol

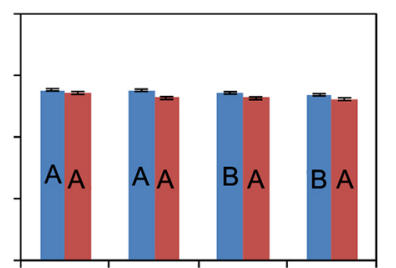

Site 2 - medium texture Oxisol

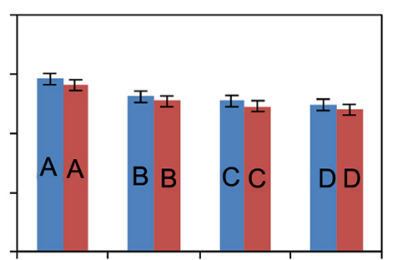

Site 3 - sandy Ultisol

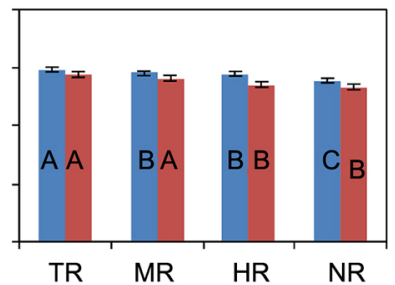

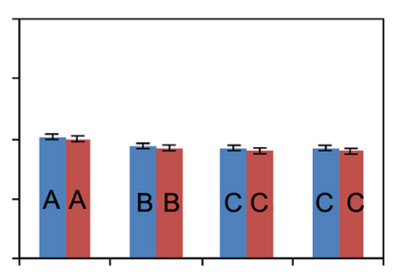

(240 DAH)
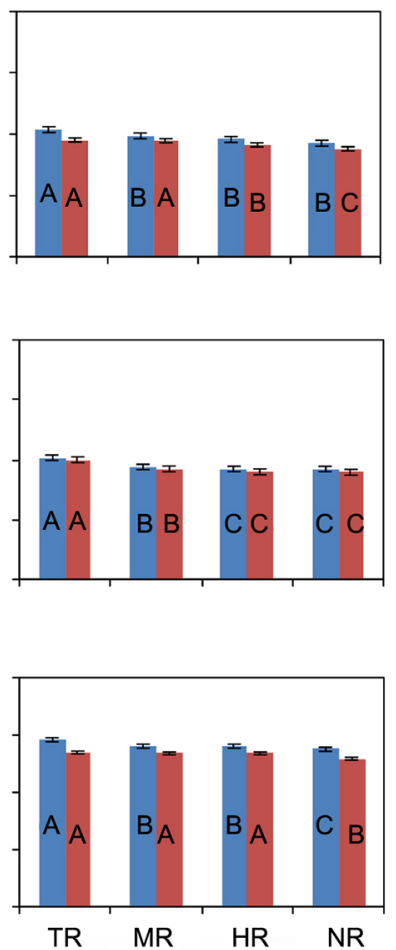

Figure 4 - Soil temperature at the 0 - to 5 - and 5- to 10-cm depths under sugarcane straw removal rates (TR = total removal; MR = medium removal; $\mathrm{HR}=$ high removal and NR = no removal) after 30, 120 and 240 days after harvesting (DAH) of sugarcane. i) clayey Oxisol; ii) medium texture Oxisol and iii) sandy Ultisol. *Same letter within bars (for each depth), did not differ between themselves according to Tukey's test $(p<0.05)$.

Site 1 - clayey Oxisol Site 2 - medium texture Oxisol Site 3 - sandy Ultisol —TR - MR … Air temp $\left({ }^{\circ} \mathrm{C}\right)-\mathrm{HR}-\mathrm{NR}$


$(5-10 \mathrm{~cm})$

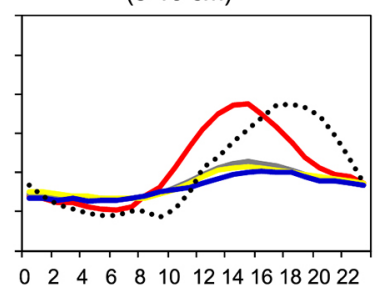

Figure 5 - Hourly soil temperature at the 0 - to 5 - and 5 - to $10-\mathrm{cm}$ depths under sugarcane straw removal rates (TR $=$ total removal; MR $=$ medium removal; $H R=$ high removal and $\mathrm{NR}=$ no removal). i) clayey Oxisol (03 Dec 2015); ii) medium texture 0xisol (05 Feb 2016 ) and iii) sandy Ultisol (22 Set 2016). 
Site 1 - clayey Oxisol Site 2 - medium texture Oxisol Site 3 - sandy Ultisol

Rainfall (mm)
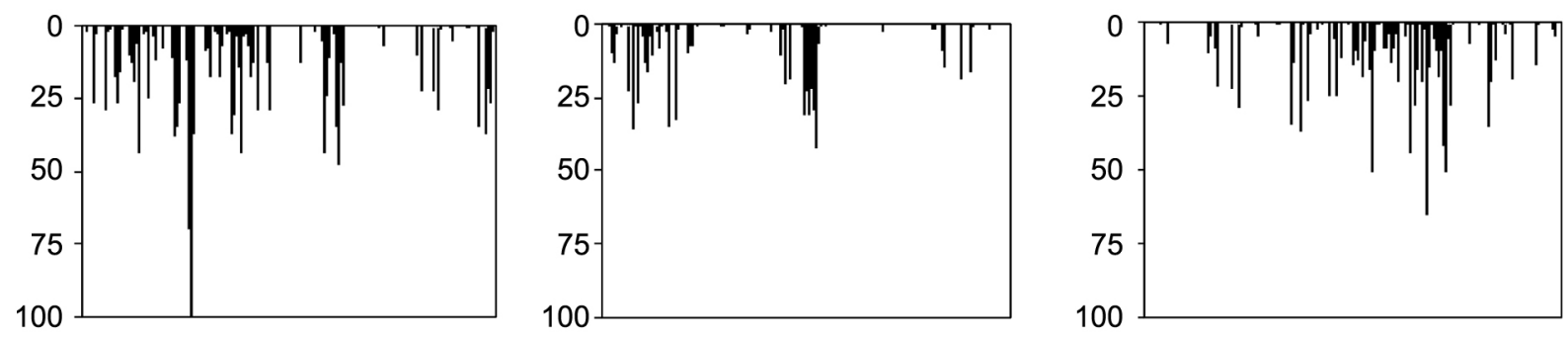

Soil moisture

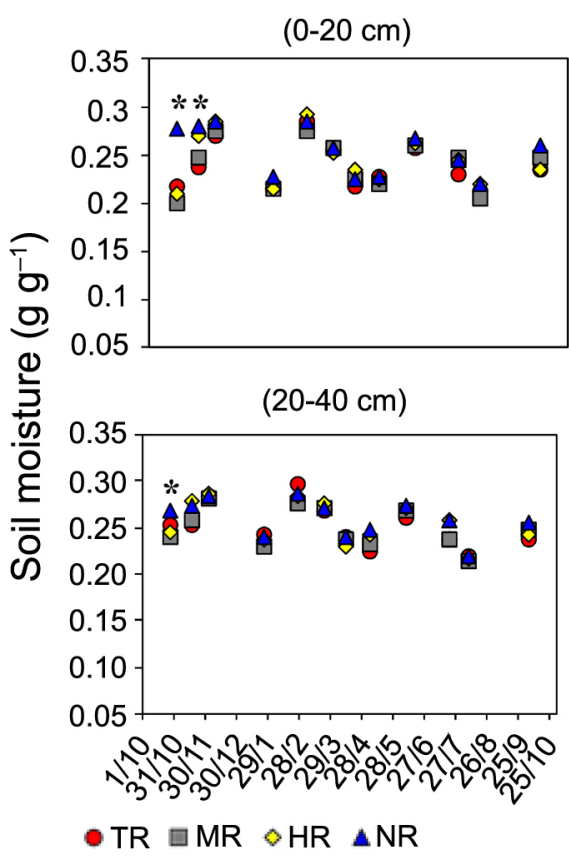

$(0-20 \mathrm{~cm})$

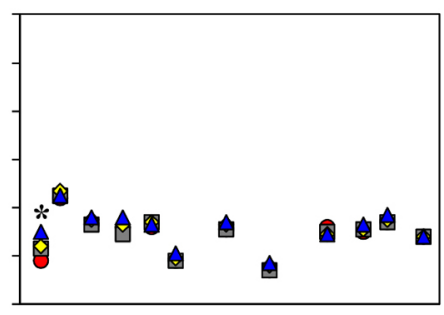

$(20-40 \mathrm{~cm})$



$(0-20 \mathrm{~cm})$

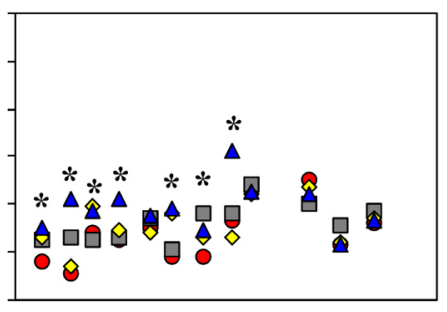

$(20-40 \mathrm{~cm})$

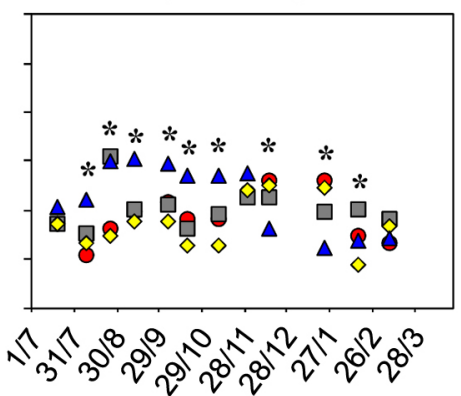

Days during sugarcane growing cycle

Figure 6 - Rainfall and average of soil moisture at 0 - to 20- and 20- to 40-cm depths under sugarcane straw removal rates (TR = total removal; $\mathrm{MR}=$ medium removal; $\mathrm{HR}=$ high removal and $\mathrm{NR}=$ no removal). i) clayey Oxisol; ii) medium texture Oxisol and iii) sandy Ultisol. The asterisk $\left({ }^{*}\right)$ indicates a statistical difference $\left(F^{\prime}\right.$ test $\left.<0.05\right)$ on the same date.

in different Brazilian regions (Awe et al., 2015; Corrêa et al., 2019) and in other countries with sugarcane and other crops (Table 3).

Sugarcane straw removal can increase the soil surface temperature and thermal amplitude up to $7^{\circ} \mathrm{C}$ and $10.6^{\circ} \mathrm{C}$, respectively (Oliveira et al., 2001; Awe et al., 2015). In fact, the straw layer acts as a thermal insulator that reduces the soil heating during the day and the loss of heat to the atmosphere at night. The reflectivity (albedo) of straw is more significant than those in bare soil (Liu et al., 2014), which reduces the amount of energy available for heating the straw-surface layer.

Clayey soils have higher heat conduction and water retention capacity, as a result of their higher microporosity (water retention) and organic matter content (Bowers and Hanks, 1965), compared to sandy soils. Since water is a more efficient heat conductor than the air, the heat reaching the soil is rapidly conducted to deeper soil layers (Sinclair and Weiss, 2010). These factors contribute to keeping lower surface temperatures in the clayey soils than the sandy soils (Sinclair and Weiss, 2010). Thus, the maintenance of straw on the soil surface has a fundamental role in reducing high temperatures (mainly in the sandy soils) due to their large heating capacity (Sandhu et al., 2013).

In addition to affecting water evaporation, the soil temperature also affects gas diffusion in the soil (Hillel, 1998). The soil composition, density, moisture, and 
cover are the main factors influencing soil temperature variation (Baver et al., 1972). Soil temperature affects reactions and biological activity in the soil (Järvan et al., 2014), modulating decomposition and nutrient cycling processes (Sousa et al., 2017), as well as seed germination or budding of plants (Sándor and Fodor, 2012).

The maintenance of sugarcane straw in warm periods is essential to decreasing high soil temperatures and preserving the soil moisture. Although a number of studies have shown that, especially during the winter, sugarcane straw removal may also facilitate sprouting and tillering of sugarcane (Sousa et al., 2017; Lisboa et al., 2019), possibly due to the maintenance of higher soil temperatures. This improvement would be associated with: i) greater heating of the soil without straw; ii) increase in the intensity and amount of solar radiation that reaches the sugarcane ratoon; iii) removal of the physical barrier formed by the straw left on the sugarcane ratoon. All these effects induced the sugarcane sector to adopt the raked (raking straw to inter-rows) practice, which recently discovered that, despite providing these benefits in the initial period of plant development, failed to generate increases in productivity (Lisboa et al., 2019).

Impacts on sugarcane yield may vary from region to region (Carvalho et al., 2019). In this study, for the central region of São Paulo there was no significant yield loss, which was attributed, among other aspects, to the lower average temperature in that region compared with other sugarcane-producing regions of the country. The highest yield reductions due to straw removal were observed in the western region of São Paulo, where there is a predominance of sandy soils, and in southern Goiás, where the water deficit period is longer than other regions. Such study revealed that straw removal is associated with crop yields, due to the fundamental role of straw in regulating temperature, and particularly in the short term, in maintaining the soil moisture, both in sandy soils with lesser water retention capacity and in clayey soils during prolonged periods of drought.

\section{Effect of sugarcane straw removal on soil moisture}

Especially during dry and warm periods, the maintenance of straw on the soil's surface reduces soil water losses from evaporation and protects the soil against the incidence of direct solar radiation. In this study, soil moisture was assessed at the $0-$ to $20-\mathrm{cm}$ and 20 - to $40-\mathrm{cm}$ layers, aiming to evaluate the impact that soil temperature can have on soil moisture in deeper layers. Several researchers have evaluated soil moisture as affected by crop residues, such as black oat, maize, and sorghum (Furlani et al., 2008; Zhao et al., 2014; Teame et al., 2017) (Table 3). However, only a few studies have investigated the influence of sugarcane straw on soil moisture, especially in different soil textures and deeper layers.

Based on our results, the maintenance of up to $0.07 \mathrm{~g} \mathrm{~g}^{-1}$ of soil moisture in clayey (wet season) and sandy (dry season) soils in the 0 - to 20 -cm layer (Figure 6; Table 3) - the main zone of root growth and activity, in MR and NR represents a gain of about $150 \mathrm{~L} \mathrm{~m}^{2}$ of water to the soil for each treatment. Considering that sugarcane has an average daily water demand of $6 \mathrm{~mm}$, this value would represent a ten-day water supply for the crop, ensuring good sprouting after the harvest.

In Brazil, other authors have reported reductions of 0.01 and $0.08 \mathrm{~g} \mathrm{~g}^{-1}$ due to straw removal (Peres et al., 2010; Awe et al., 2015; Corrêa et al., 2019). Our data is also in line with previous simulations performed by Gmach et al. (2019), who estimated that the complete maintenance of straw $\left(12 \mathrm{Mg} \mathrm{ha}^{-1}\right)$ or even partial maintenance $(6 \mathrm{Mg}$ $\mathrm{ha}^{-1}$ ) delays the water-limiting condition in plants for approximately one month compared to bare soil (total removal) during the dry season in the state of São Paulo. However, even an increase of $0.03 \mathrm{~g} \mathrm{~g}^{-1}$ in soil moisture noted in medium soil represents a gain of about $64 \mathrm{~L}$ $\mathrm{m}^{2}$ (four-day water supply for the crop). These results were observed during the initial growth phase, which confirms the straw layer's importance, especially in sandy soils. This is even more important for the sandy soil since it was observed during the dry season that sandy soils are characterized by low water retention.

In the subsurface layer (20- to $40-\mathrm{cm}$ in depth) of clayey soil, in MR and NR, a slight decrease in soil moisture was observed (Figure 6; Table 3), which may be the result of its different granulometric composition (Table 1). Clayey soils may have a slower flow at lower depths since the water in soil micropores is strongly retained by clay particles. However, this can assist in sugarcane development since most of the roots are found in this layer (Melo et al., 2020). On the other hand, sandy soil presented higher soil moisture in the 20- to 40-cm layer due to its high macroporosity and low aggregation, causing water to percolate very quickly and retain much less than medium and clayey soils (Osman, 2013; Graham and Indorante, 2017).

A recent study revealed that water deficit is considered the main factor associated with reductions in sugarcane yield in Brazil (Dias and Sentelhas, 2018). This researchers evaluated several Brazilian regions that presented a well-defined dry season (from Apr to Sept) - at which time the crop is exposed to high water stress conditions - and reported that sugarcane straw has a key role in preserving soil moisture and helping in sprouting, growth, and development of the crop.

During the sugarcane cycle, the linear growth phase is usually reached between 108 and 206 days (Lisboa et al., 2018). In this growth period, adequate soil moisture levels stimulate sugarcane growth, cane elongation, and internode formation (Humbert, 1963). Even with minor differences found in the soil moisture (Figure 5; Table 3), sugarcane yield can be significantly influenced (Corrêa et al., 2019), thereby reinforcing the importance of straw maintenance in reducing water stress on plants. Nevertheless, even if the beneficial effect on yields are not significant in the humid regions 
of Brazil, such as São Paulo, Vianna et al. (2020) have recently showed that the maintenance of $12 \mathrm{Mg} \mathrm{ha}^{-1}$ was associated with a high probability (> $87 \%$ ) of reducing the water use of sugarcane cropping system by $89 \mathrm{~mm}$, on average, potentially reducing irrigation demand in the early stages of crop development while protecting crop production under dry spell events. Therefore, in addition to agronomic gains, the economic and environmental benefits of straw maintenance in the field should not be disregarded.

The lower soil moisture in the 0 - to 20 -cm layer at the beginning of the cycle (in the three soil textures) may be related to a higher evaporation rate since this layer is more exposed to solar radiation. Furthermore, the roots absorb water from this layer, in which a large part of the root system is found (Melo et al., 2020). However, even in a lesser quantity, these values represent a significant increase during the initial growth phase. At the end of the sugarcane cycle these differences in soil moisture were not significant, due to total shading of the soil surface caused by the sugarcane canopy, which conferred the same conditions for all treatments (Aquino et al., 2015). In these periods, the decomposition process of the residue is already advanced, leaving about 30 to $40 \%$ of straw on the soil surface (Aquino et al., 2015; Sousa et al., 2017).

Overall, variation in soil moisture content depends on several factors, such as soil texture and structure, organic matter content, and mineralogy (Kirkham, 2014). Among them, the texture is the main factor since it defines the particles' specific surface area and the size of the pores. The smaller particle had a larger specific surface area, and, consequently, more water will be retained by adsorption (Klein, 2012), as was observed in our clayey soil. Due to the higher water retention by adsorption and greater microporosity, clayey soils retain higher water volumes than sandy soils. Moreover, clayey soils have high colloidal material (clay and organic matter) content that promote higher water retention (Osman, 2013).

\section{Conclusions}

Intensive sugarcane straw removal (SR and TR) promoted an increase in soil temperature of between $2{ }^{\circ} \mathrm{C}$ and $3{ }^{\circ} \mathrm{C}$ and in thermal amplitude between 5 and $9{ }^{\circ} \mathrm{C}$ in the 0 - to $5-\mathrm{cm}$ layer, compared to moderate or no straw removal (MR and NR). The impacts on soil temperature induced by straw removal are more intense in the warmer hours of the day (15h00 to 18h00). They are particularly relevant to the initial growth phase, when the plant canopy does not entirely shade the soil.

Soil moisture decreased between 0.03 to $0.07 \mathrm{~g} \mathrm{~g}^{-1}$ in the 0 - to 20-cm layer in SR and TR, showing that high temperature impacts are not limited to the superficial layers. This effect was observed mainly during the initial growth phase when an abundant water supply is needed for sprouting, particularly during the dry season.
Sandy soils are more susceptible to straw removal than clay soils. In this regard, straw maintenance on the soil surface plays an essential role in temperature regulation and preservation of higher soil moisture in these soils, especially in regions with severe water deficits and long periods of water stress. Our findings help to affirm this since sandy soil increased the soil temperature by up to $3{ }^{\circ} \mathrm{C}$ and decreased $0.07 \mathrm{~g} \mathrm{~g}^{-1}$ in the soil moisture during the dry season with substantial and total straw removal (SR and TR).

Straw removal management for bioenergy production requires careful planning, that prioritizes low or moderate rates in soils less responsive to straw (e.g., clayey soils), thereby reducing negative impacts on soil functions and plant growth.

\section{Acknowledgments}

This study is dedicated to the memory of Dr. Carlos C. Cerri. The Brazilian Development Bank (BNDES) provided funding support for this research (Project \#14.2.0773.1). This study was funded in part by the Coordination for the Improvement of Higher Level Personnel (CAPES) - Finance Code 001. The first author thanks the CAPES. The second author thanks the São Paulo Research Foundation (FAPESP - \#2019/25988-5) for providing his scholarship. The fourth author thanks the São Paulo Research Foundation (FAPESP Process \#2018/09845-7). We also thank Admilson Margato, Willian Gabriel, and Vinicius Michelon for their assistance in carrying out the experiment.

\section{Author's Contributions}

Conceptualization: Santos, A.K.B.; Popin, G.V.; Gmach, M.R.; Cherubin, M.R.; Siqueira-Neto, M.; Cerri, C.E.P. Data acquisition: Santos, A.K.B.; Popin, G.V. Data analysis: Santos, A.K.B.; Cherubin, M.R. Design of methodology: Santos, A.K.B.; Cherubin, M.R.; Siqueira-Neto, M.; Cerri, C.E.P. Writing and editing: Santos, A.K.B.; Popin, G.V.; Gmach, M.R.; Cherubin, M.R.; Siqueira-Neto, M.; Cerri, C.E.P.

\section{References}

Alvares, C.A.; Stape, J.L.; Sentelhas P.C.; Gonçalves, J.L.M.; Sparovek, G. 2013. Köppen's climate classification map for Brazil. Meteorologische Zeitschrift 22: 711-728. https://doi.10.1127/09412948/2013/0507

Aquino, G.S.; Medina, C.C.; Porteira Junior, A.L.P.; Santos, L.O.; Cunha, A.C.B.; Kussaba, D.A.O.; Santos Júnior, J.H.; Almeida, L.F.; Santiago, A.D. 2015. Root system and productivity of sugarcane ratoon associated to different quantities of straw. Pesquisa Agropecuária Brasileira 50: 1150-1159 (in Portuguese, with abstract in English). https://doi.org/10.1590/S0100204X2015001200004

Awan, A. 1964. Influence of mulch on soil moisture, soil temperature and yield of potatoes. American Journal of Potato Research 41: 337-339. https://doi.org/10.1007/BF02855669 
Awe, G.O.; Reichert, J.M.; Wendroth, O.O. 2015. Temporal variability and covariance structures of soil temperature in a sugarcane field under different management practices in southern Brazil. Soil Tillage Research 150: 93-106. https:// doi.org/10.1016/j.still.2015.01.013

Baver, L.; Gardner, W.; Gardner, W. 1972. Soil Physics. 4ed. John Wiley, New York, NY, USA.

Bordonal, R.O.; Menandro, L.M.S.; Barbosa, L.C.; Lal, R.; Milori, D.M.B.P.; Kolln, O.T.; Franco, H.C.J.; Carvalho, J.L.N. 2018. Sugarcane yield and soil carbon response to straw removal in south-central Brazil. Geoderma 328: 79-90. https://doi.org/10.1016/j.geoderma.2018.05.003

Bowers, S.A.; Hanks, R.J. 1965. Reflection of radiant energy from soils. Soil Science 100: 130-138. https:// doi.10.1097/00010694-196508000-00009

Carvalho, J.L.N.; Menandro, L.M.S.; Castro, S.G.Q.; Cherubin, M.R.; Bordonal, R.O.; Barbosa, L.C.; Gonzaga, L.C.; Tenelli, S.; Franco, H.C.J.; Kolln, O.T.; Castioni, G.A.F. 2019. Multilocation straw removal effects on sugarcane yield in south-central Brazil. Bioenergy Research 12: 813-829. https://doi.org/10.1007/s12155-019-10007-8

Castioni, G.A.; Cherubin, M.R.; Menandro, L.M.S.; Sanches, G.M.; Bordonal, R.O.; Barbosa, L.C.; Franco, H.C.J.; Carvalho, J.L.N. 2018. Soil physical quality response to sugarcane straw removal in Brazil: a multi-approach assessment. Soil Tillage Research 184: 301-309. https://doi. org/10.1016/j.still.2018.08.007

Chen, S.; Hong, H.; Huang, X.; Fang, Q.; Yin, K.; Wang, C. Zhang, Y.; Cheng, L.; Algeo, T.J. 2018. The role of organoclay associations in limiting organic matter decay : insights from the Dajiuhu peat soil, central China. Geoderma 320: 149-160. https://doi.org/10.1016/j.geoderma.2018.01.013

Chen, S.Y.; Zhang, X.Y.; Pei, D.; Sun, H.Y.; Chen, S.L. 2007. Effects of straw mulching on soil temperature, evaporation and yield of winter wheat: field experiments on the north China Plain. Annals of Applied Biology 150: 261-268. https:// doi.org/10.1111/j.1744-7348.2007.00144.x

Cherubin, M.R.; Bordonal, R.O.; Castioni, G.A.; Guimarães, E.M.; Lisboa, I.P.; Moraes, L.A.A.; Menandro, L.M.S.; Tenelli, S.; Cerri, C.E.P.; Karlen, D.L.; Carvalho, J.L.N. 2021. Soil health response to sugarcane straw removal in Brazil. Industrial Crops and Production 163: 113315. https://doi. org/10.1016/j.indcrop.2021.113315

Cherubin, M.R.; Lisboa, I.P.; Silva, A.G.B.; Varanda, L.L.; Bordonal, R.O.; Carvalho, J.L.N.; Otto, R.; Pavinato, P.S.; Soltangheisi, A.; Cerri, C.E.P. 2019. Sugarcane straw removal: implications to soil fertility and fertilizer demand in Brazil. Bioenergy Research 12: 888-900.

Coelho, M.E.H.; Freitas, F.C.L.; Cunha, J.L.X.L.; Silva, K.S.; Grangeiro, L.C.; Oliveira, J.B. 2013. The effect of soil covers on temperature range and yield of sweet pepper. Planta Daninha 31: 369-378 (in Portuguese, with abstract in English).

Corrêa, S.T.; Barbosa, L.C.; Menandro, L.M.S.; Scarpare, F.V.; Reichardt, K.; Moraes, L.O.; Hernandes, T.A.D.; Franco, H.C.J.; Carvalho, J.L.N. 2019. Straw removal effects on soil water dynamics, soil temperature, and sugarcane yield in south-central Brazil. Bioenergy Research 12: 749-763.
Dias, H.B.; Sentelhas, P.C. 2018. Sugarcane yield gap analysis in Brazil: a multi-model approach for determining magnitudes and causes. Science of Total Environmet 637-638: 1127-1136.

Digonzelli, P.A.; Tonatto, M.J.; Romero, E.R.; Sanzano, G.A.; Fernández de Ullivarri, J.; Giardina, J.A.; Scandaliaris, J. 2011. Assessing a sustainable sugar cane production system in Tucumán, Argentina. Part 2. Soil water and thermal regime, stalk population dynamics and sugarcane production. Revista Industrial y Agrícola de Tucumán 88: 1-12.

Dourado Neto, D.; Timm, L.C.; Cesar, J.; Oliveira, M.; Oliveira, O.; Bacchi, S.; Tominaga, T.T.; Meira, F.A. 1999. State-space approach for the analysis of soil water content and temperature in a sugarcane crop. Scientia Agricola 56: 1215-1221.

Furlani, C.E.A.; Gamero, C.A.; Levien, R.; Silva, R.P.; Cortez, J.W. 2008. Soil temperature as affected by soil tillage and management of winter cover crops. Revista Brasileira de Ciência do Solo 32: 375-380 (in Portuguese, with abstract in English).

Gasparim, E.; Ricieri, R.; Silva, S.; Dallacort, R.; Gnoatto, E. 2005. Temperature in soil profile using two densities of mulching and nude soil. Acta Scientiarum. Agronomy 27: 107-115 (in Portuguese, with abstract in English).

Graham, R.C.; Indorante, S.J. 2017. The Soils of the USA: Concepts of Soil Formation and Soil Survey. Springer, Cham, Switzerland.

Hillel, D. 1998. Environmental Soil Physics. 3ed. Academic Press, San Diego, CA, USA.

Humbert, R.D. 1963. The Growing of Sugar Cane. Elsevier, New York, NY, USA.

Järvan, M.; Edesi, L.; Adamson, A.; Võsa, T. 2014. Soil microbial communities and dehydrogenase activity depending on farming systems. Plant Soil Environment 60: 459-463.

Johnson, J.M.F.; Strock, J.S.; Tallaksen, J.E.; Reese, M. 2016. Corn stover harvest changes soil hydrology and soil aggregation. Soil Tillage Research 161: 106-115.

Kirkham, M.B. 2014. Principles of Soil and Plant Water Relations. 2ed. Academic Press, New York, NY, USA.

Klein, V.A. 2012. Soil Physics = Física do Solo. 2ed. Editora Universidade de Passo Fundo, Passo Fundo, RS, Brazil (in Portuguese).

Kosterna, E. 1989. The effect of covering and mulching on the soil temperature, growth and yield of tomato. Folia Horticulturae 26: $91-101$.

Lal, R. 1974. No tillage effects on soil properties and mayze (Zea mays L.) production in western Nigeria. Plant and Soil 40: 321331.

Leal, M.R.L.V.; Galdos, M.V.; Scarpare, F.V.; Seabra, J.E.A.; Walter, A.; Oliveira, C.O.F. 2013. Sugarcane straw availability, quality, recovery and energy use: a literature review. Biomass and Bioenergy 53: 11-19.

Lisboa, I.P.; Cherubin, M.R.; Cerri, C.C.; Cerri, D.G.P.; Cerri, C.E.P. 2017. Guidelines for the recovery of sugarcane straw from the field during harvesting. Biomass and Bioenergy 96: 69-74.

Lisboa, I.P.; Cherubin, M.R.; Lima, R.P.; Gmach, M.R.; Wienhold, B.J.; Schmer, M.R.; Jin, V.L.; Junior, E.F.F.; Guerra, H.P.; Cerri, C.C.; Cerri, C.E.P. 2019. Sugarcane straw blanket management effects on plant growthx, development, and yield in southeastern Brazil. Crop Science 1744: 1732-1744. 
Lisboa, I.P.; Cherubin, M.R.; Lima, R.P.; Cerri, C.C.; Satiro, L.S.; Wienhold, B.J.; Schmer, M.R.; Jin, V.L.; Cerri, C.E.P. 2018. Sugarcane straw removal effects on plant growth and stalk yield. Industrial Crops and Products 111: 794-806.

Liu, Y.; Wang, J.; Liu, D.; Li, Z.; Zhang, G.; Tao, Y.; Xie, J.; Pan, J.; Chen, F. 2014. Straw mulching reduces the harmful effects of extreme hydrological and temperature conditions in citrus orchards. PLoS One 9: e87094.

Melo, P.L.A.; Cherubin, M.R.; Gomes, T.C.A.; Lisboa, I.P.; Satiro, L.S.; Cerri, C.E.P.; Siqueira-Neto, M. 2020. Straw removal effects on sugarcane root system and stalk yield. Agronomy 10: e1048.

Nyborg, M.; Malhi, S. 1989. Effect of zero and conventional tillage on barley yield and NO3-N content, moisture and temperature of soil in north-central Alberta. Soil Tillage Research 15: 1-9.

Oliveira, J.C.M.; Timm, L.C.; Tominaga, T.T.; Cássaro, F.A.M.; Reichardt, K.; Bacchi, O.O.S.; Dourado Neto, D.; De, G.M. 2001. Soil temperature in a sugar-cane crop as a function of the management system. Plant Soil 230: 61-66.

Oliveira, N.; Ruiz, H.; Costa, L.; Schaefer, C.E.G. 2005. Soil temperature and moisture fluctuations in response to vegetation cover. Revista Brasileira de Engenharia Agrícola e Ambiental 9: 535-539 (in Portuguese, with abstract in English).

Osman, K. 2013. Soils: Principles, Properties and Management. Springer, Dordrecht, The Netherlands.

Paredes, F.P.; Portilho, I.I.R.; Mercante, F.M. 2015. Microbiological attributes of the soil under cultivation of sugar cane with and without burning straw. Semina. Ciências Agrárias 36: 151-164 (in Portuguese, with abstract in English).

Peres, J.G.; Souza, C.F.; Lavorenti, N.A. 2010. Evaluation of the effects of sugarcane straw coverage in moisture and water loss of soil. Engenharia Agrícola 30: 875-886 (in Portuguese, with abstract in English).

Prevedello, C.L. 2010. Soil thermal energy = Energia térmica do solo. p. 178-211. In: Lier, Q.J. van, ed. Física do solo. Sociedade Brasileira de Ciência do Solo, Viçosa, MG, Brazil (in Portuguese).

Rede Interuniversitária para o Desenvolvimento do Setor Sucroenergético [Ridesa]. 2010. National Catalog of "RB" Sugarcane Varieties = Catálogo nacional de Variedades "RB" de Cana-de-Açúcar. Ridesa, Araras, SP, Brazil (in Portuguese).

Ribas, G.G.; Streck, N.A.; Silva, S.D.; Rocha, T.S.M.; Langner, J.A. 2015. Effect of irrigation and mulching on soil temperature. Engenharia Agrícola 4430: 817-828 (in Portuguese, with abstract in English).
Sandhu, H.S.; Gilbert, R.A.; Kingston, G.; Subiros, J.F.; Morgan, K.; Rice, R.W.; Baucum, L.; Shine Jr, J.M.; Davis, L. 2013. Effects of sugarcane harvest method on microclimate in Florida and Costa Rica. Agricultural and Forest Meteorology 177: 101-109.

Sándor, R.; Fodor, N. 2012. Simulation of soil temperature dynamics with models using different concepts. Science World Journal 2012: 1-8.

Sinclair, T.; Weiss, A. 2010. Principles of Ecology in Plant Production. 2ed. CABI, Wallingford, UK.

Sousa, J.G.D.A.; Cherubin, M.R.; Cerri, C.E.P.; Cerri, C.C.; Feigl, B.J. 2017. Sugar cane straw left in the field during harvest: decomposition dynamics and composition changes. Soil Research 55: 758-768.

Teame, G.; Tsegay, A.; Abrha, B. 2017. Effect of organic mulching on soil moisture, yield, and yield contributing components of sesame (Sesamum indicum L.). International Journal of Agronomy 2017: e4767509.

Teixeira, P.C.; Donagemma, G.K.; Fontana, A.; Teixeira, W.G. 2017. Soil Analysis Methods Manual = Manual de Métodos de Análise de Solo. 3ed. Embrapa Solos, Rio de Janeiro, RJ, Brazil (in Portuguese).

Townsend, W.N. 1977. An Introduction to the Scientific Study of the Soil. CABI, Wallingford, UK.

Valim, W.C.; Panachuki, E.; Pavei, D.S.; Sobrinho, T.A.; Almeida, W.S. 2016. Effect of sugarcane waste in the control of interrill erosion. Semina. Ciências Agrárias 37: 1155-1164.

Vianna, S.; Silveira, D.; Nassif, P.; Carvalho, S.; Ricardo, F. 2020. Modelling the trash blanket effect on sugarcane growth and water use. Computers and Electronics in Agriculture 172: 1-11.

Zhao, Y.; Pang, H.; Wang, J.; Huo, L.; Li, Y. 2014. Effects of straw mulch and buried straw on soil moisture and salinity in relation to sunflower growth and yield. Field Crops Research 161: 16-25.

Zwirtes, A.L.; Reinert, D.J.; Gubiani, P.I.; Silva, V.R.; Mulazzani, R.P.; Somavilla, A. 2017. Temperature changes in soil covered by black oat straw. Pesquisa Agropecuária Brasileira 52: 11271130 . 